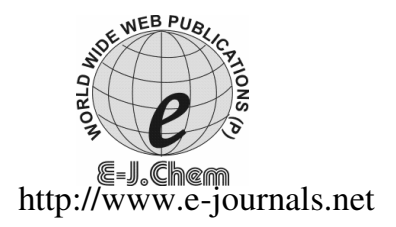

ISSN: 0973-4945; CODEN ECJHAO

E-Journal of Chemistry 2011, 8(1), 269-275

\title{
Sensitive Bromatometric Methods for the Determination of Sumatriptan Succinate in Pharmaceutical Formulations
}

\author{
K.V.V.SATYANARAYANA and P.NAGESWARA RAO* \\ Department of Chemistry, National Institute of Technology \\ Warangal -506004, Andhra Pradesh, India \\ pnraonitw07@gmail.com
}

Received 10 March 2010; Revised 31 May 2010; Accepted 25 July 2010

\begin{abstract}
Two simple and sensitive spectrophotometric methods are described for the determination of sumatriptan succinate (STS) in pure and tablets using bromate-bromide as the bromination reagent in acid medium and two dyes as subsidiary reagents. The two methods are based on the bromination of STS by a known excess of in situ generated bromine followed by determination of unreacted bromine by reacting with a fixed amount of methyl orange (Method A) or indigo carmine (Method B) and measuring the absorbance at 508 or $610 \mathrm{~nm}$. In both methods, the amount of bromine reacted corresponds to the amount of STS. The experimental conditions for the assay have been optimized. In two methods, the absorbance was found to increase linearly with the concentration of STS at the respective wavelengths. Beer's law was obeyed over the ranges 0.2-1.6 and 2.0-12.0 $\mu \mathrm{g} \mathrm{mL}^{-1}$ for method A and method B respectively and the respective molar absorptivity values were $1.898 \times 10^{5}$ and $2.71 \times 10^{4} \mathrm{~L} \mathrm{~mol}^{-1} \mathrm{~cm}^{-1}$. The statistical analysis of the methods was validated according to the present ICH guidelines. The proposed methods were applied to the analysis of tablet form of STS and the results tallied well with the label claim.
\end{abstract}

Keywords: Sumatriptan succinate, Spectrophotometry, Bromate-bromide, Tablets

\section{Introduction}

Sumatriptan succinate (STS); 3-[2-(dimethylamino) ethyl]- $N$-methyl-indole-5-ethanesul fonamide succinate $(1: 1)$ is shown in Figure 1. STS is a selective 5-hydroxy triptamine receptor subtype agonists. It is anti migraine drug, used for treating migraine headaches. It is structurally similar to serotonin. Literature survey revealed that few HPLC methods in plasma $^{1}$ and brain tissues ${ }^{2}$, HPLC-MS-MS ${ }^{3,4}$ HPLC-ECD $^{5,6}$, HPLC-coulometric ${ }^{7}$, HPLCtandem MS-MS ${ }^{8}$ and HPTLC ${ }^{9}$ methods were reported for determination of STS. So far no spectrophotometric method based on oxidation with bromate-bromide mixture have been 
reported for determination of sumatriptan in tablet forms. Two simple and sensitive spectrophotometric methods for the analysis of sumatriptan from pharmaceutical dosage forms are reported here. The methods utilize bromate-bromide mixture and methyl orange and indigo carmine as reagents, which have successfully been used for the sensitive spectrophotometric determination of many bioactive substances ${ }^{10-16}$. The proposed methods have the advantages of speed and simplicity besides being accurate and precise and can be adopted by the pharmaceutical laboratories for industrial quality control.

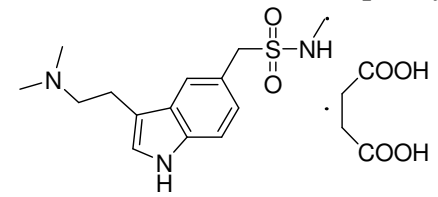

\section{Experimental}

Figure.1. Structure of sumatriptan succinate

All absorption spectra were made using UV-Vis-NIR spectrophotometer (Simadzu 1601, Japan) equipped with $1 \mathrm{~cm}$ matched quartz cells by using a personal computer loaded with the UV-PC 3.9 software package. An electronic micro balance (Sartorius MC 5, Germany) was used for weighing the solid materials

\section{Materials and reagents}

All solvents and reagents used were of analytical grade. Double-distilled water was used throughout the investigation. A stock solution equivalent to $1000 \mu \mathrm{g} \mathrm{mL}^{-1} \mathrm{KBrO}_{3}$ containing a large excess of $\mathrm{KBr}$ was prepared by dissolving accurately weighed $100 \mathrm{mg}$ of $\mathrm{KBrO}_{3}$ (Qualigens, Mumbai, India) and $1.0 \mathrm{~g}$ of $\mathrm{KBr}$ (Reidel Chemicals, India) in water and diluting to $100 \mathrm{~mL}$ in a volumetric flask. The above solution was diluted appropriately with water to get 10 and $30 \mu \mathrm{g} \mathrm{mL}^{-1} \mathrm{KBrO}_{3}$ for use in method $\mathrm{A}$ and method $\mathrm{B}$ respectively. To prepare $50 \mu \mathrm{g} \mathrm{mL}^{-1}$ methyl orange for method A, first, a $500 \mu \mathrm{g} \mathrm{mL}^{-1}$ dye solution was prepared by dissolving accurately weighed $59 \mathrm{mg}$ of dye (S.d. Fine Chem., Mumbai, India, $85 \%$ dye content) in water and diluting to $100 \mathrm{~mL}$ in a calibrated flask. It was diluted to 10 -fold to obtain the required concentration. For method B, a $1000 \mu \mathrm{g} \mathrm{mL}^{-1}$ stock standard solution was first prepared by dissolving accurately weighed $112 \mathrm{mg}$ of dye (S.d. Fine Chem., Mumbai, India, $90 \%$ dye content) in water and diluting to volume in a $100 \mathrm{~mL}$ calibrated flask. The solution was then diluted 5-fold to get the working concentration of $200 \mu \mathrm{g} \mathrm{mL} \mathrm{L}^{-1}$. Hydrochloric acid $(\sim 5 \mathrm{M})$ was prepared by diluting required volume of concentrated acid (S.d.fine-chem Ltd., Mumbai, India) to $100 \mathrm{~mL}$ with water for two methods.

Standard STS was procured from MSN laboratories, Hyderabad, India. A stock standard solution containing $500 \mu \mathrm{g} \mathrm{mL} \mathrm{m}^{-1}$ of STS was prepared by dissolving accurately weighed $50 \mathrm{mg}$ of pure drug in a $100 \mathrm{~mL}$ of calibrated flask with double distil water. The solution was further diluted with distil water to get working concentrations of 20 and $50 \mu \mathrm{g} \mathrm{mL}{ }^{-1}$ STS for two methods.

\section{Method using methyl orange (Method A)}

Aliquots $(0.1$ to $0.8 \mathrm{~mL})$ of standard STS solution $\left(20 \mu \mathrm{g} \mathrm{mL}^{-1}\right)$ corresponding to $0.2-1.6 \mu \mathrm{g} \mathrm{mL}^{-1}$ were transferred into a series of $10 \mathrm{~mL}$ calibrated flasks. To each flask was added $1 \mathrm{~mL}$ of $5 \mathrm{M}$ hydrochloric acid followed by $1.3 \mathrm{~mL}$ of bromate-bromide mixture $\left(10 \mu \mathrm{g} \mathrm{mL}^{-1}\right.$ w.r.t $\mathrm{KBrO}_{3}$ ). The content was mixed well and the flasks were set aside for 25 min with occasional shaking. Finally, $1.3 \mathrm{~mL}$ of $50 \mu \mathrm{g} \mathrm{mL} \mathrm{m}^{-1}$ methyl orange solution was added to each flask, diluted to the mark with water and the absorbance of solution was measured at $508 \mathrm{~nm}$ against distilled water after 3 min. 


\section{Method using indigo carmine (Method B)}

Aliquots $(0.4$ to $2.4 \mathrm{~mL})$ of standard STS solution $\left(50 \mu \mathrm{g} \mathrm{mL}^{-1}\right)$ corresponding to 2.0 $12.0 \mu \mathrm{g} \mathrm{mL}^{-1}$ were transferred into a series of $10 \mathrm{~mL}$ calibrated flasks. To each flask was added $1 \mathrm{~mL}$ of $5 \mathrm{M}$ hydrochloric acid followed by $1.5 \mathrm{~mL}$ of bromate-bromide mixture (30 $\mu \mathrm{g} \mathrm{mL}{ }^{-1}$ w.r.t $\mathrm{KBrO}_{3}$ ). The content was mixed well and the flasks were set aside for $20 \mathrm{~min}$ with occasional shaking. Finally, $1.0 \mathrm{~mL}$ of $200 \mu \mathrm{g} \mathrm{mL}^{-1}$ indigo carmine solution was added to each flask, diluted to the mark with water and the absorbance of solution was measured at $610 \mathrm{~nm}$ against distilled water after $3 \mathrm{~min}$.

In either spectrophotometric method, a calibration graph was prepared by plotting the absorbance versus the concentration of STS. Unknown concentration was read from the calibration graph or calculated from the respective regression equation derived using the Beer's law data.

\section{Procedure for pharmaceutical formulations}

Sumatriptan succinate containing ten tablets were weighed and ground into a fine powder. An amount of the powder equivalent to $10 \mathrm{mg}$ of STS was weighed into a $100 \mathrm{~mL}$ volumetric flask, $40 \mathrm{~mL}$ water added and shaken thoroughly for about $15 \mathrm{~min}$. The volume was diluted to the mark with water, mixed well and filtered using Whatmann No. 41 filter paper. The filtrate was diluted stepwise to get 20 and $50 \mu \mathrm{g} \mathrm{mL}^{-1}$ STS for use in spectrophotometric methods A and $\mathrm{B}$ respectively. A suitable aliquot was then subjected to analysis.

\section{Results and Discussion}

The proposed spectrophotometric methods are indirect and are based on the determination of the residual bromine (in situ generated) after allowing the reaction between STS and a measured amount of bromine to be complete. The residual bromine was determined by reacting it with a fixed amount of methyl orange, indigo carmine or rhodamine $\mathrm{B}$. The methods make use of bleaching action of bromine on the dyes, the discoloration being caused by the oxidative destruction of the dyes. STS, when added in increasing amounts to a fixed amount of in situ generated bromine, consumes the latter proportionally and there occurs a concomitant fall in the amount of bromine. When a fixed amount of dye was added to decreasing amounts of bromine, a concomitant increase in the concentration of dye results. Consequently, a proportional increase in the absorbance at the respective $\lambda_{\max }$ was observed with increasing concentration of STS.

\section{Effect of acid}

In order to determine the most suitable acid for the reaction, different acids (sulfuric, hydrochloric, nitric and acetic) were tested. The results revealed that hydrochloric acid was found to be the best medium for the both steps involved in two methods. The reaction between STS and bromine (in situ) was unaffected when $0.5-2.5 \mathrm{~mL}$ of $5 \mathrm{M}$ hydrochloric acid was used. Hence, $1.0 \mathrm{~mL}$ of $5 \mathrm{M} \mathrm{HCl}$ was used for both steps of the reaction. At lower acid concentrations, the bleaching took a longer time for quantitative reaction between STS and bromine (in situ).

\section{Reaction time and stability of color}

The reaction between STS and in situ bromine was completed at room temperature $\left(25 \pm 5{ }^{\circ} \mathrm{C}\right)$ within 25 and 20 min for method A and method B, respectively (Figure.2). A time span of 3 to $5 \mathrm{~min}$ for the reaction between unreacted bromine and dyes in the second step yielded the constant and maximum absorbance. The absorption spectra of the colored species measured at 
respective wavelengths as shown in Figures 3 and 4. The contact time of 25 or $20 \mathrm{~min}$ is not critical and any delay up to $30 \mathrm{~min}$ in either method had no effect on the absorbance. The measured color in both methods was stable for several hours even in the presence of reaction product.

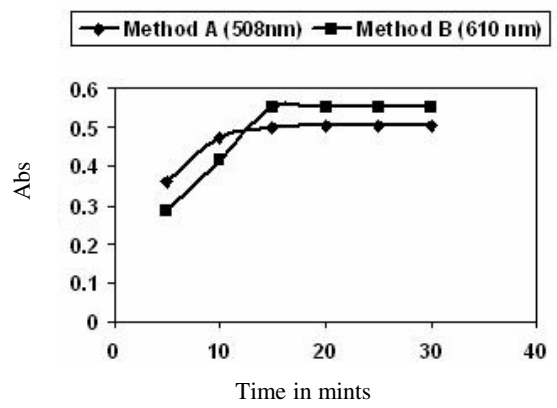

Figure 2. Effect of time on $1.0 \mu \mathrm{g} \mathrm{mL}^{-1}$ and $8 \mu \mathrm{g} \mathrm{mL}^{-1}$ of STS for method A and method B respectively

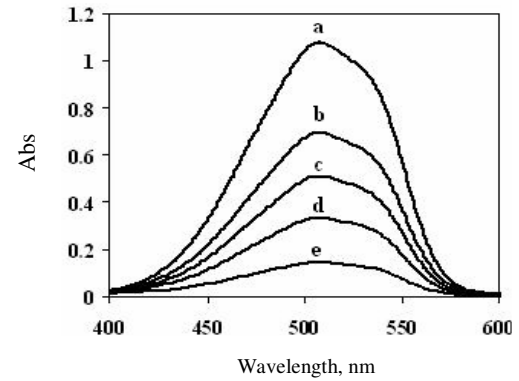

Figure 3. (a) Blank (without STS) (b) $1.4 \mu \mathrm{g} \mathrm{mL}^{-1}$ (c) $1.0 \mu \mathrm{g} \mathrm{mL}^{-1}(\mathrm{~d}) 0.6 \mu \mathrm{g} \mathrm{mL}^{-1}$ (e) $0.2 \mu \mathrm{g} \mathrm{mL}{ }^{-1}$ measured against water

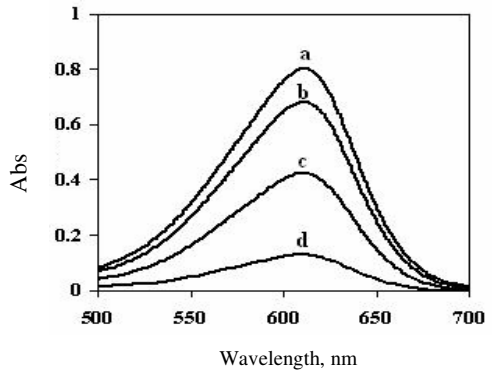

Figure 4. (a) Blank (without STS) (b) $10.0 \mu \mathrm{g} \mathrm{mL}{ }^{-1}$ (c) $6.0 \mu \mathrm{g} \mathrm{mL} \mathrm{m}^{-1}(\mathrm{~d})$ $2.0 \mu \mathrm{g} \mathrm{mL}^{-1}$ measured against water

\section{Effect of bromate /bromide mixture and dye}

A preliminary experiment was performed to fix the linear range for the bromine (in situ) under the optimum experimental conditions using the methyl orange (method A) and indigo carmine (Method B). Experiments were performed using $1.0 \mathrm{~mL}$ of $5 \mathrm{M}$ hydrochloric acid with varying volumes of bromate-bromide mixture. The decrease in absorbance was found to be linear up to 1.3 of $10 \mu \mathrm{g} \mathrm{mL}^{-1}$ of bromine with $1.3 \mathrm{~mL}$ of $50 \mu \mathrm{g} \mathrm{mL}^{-1}$ methyl orange for method A and $1.5 \mathrm{~mL}$ $30 \mu \mathrm{g} \mathrm{mL}^{-1}$ of bromine with $1.0 \mathrm{~mL} 200 \mu \mathrm{g} \mathrm{mL}^{-1}$ of indigo carmine for method B.

\section{Effect of sequence of addition}

The maximum absorbance and highest stability were obtained when the order of addition is: STS drug- hydrochloric acid- bromate / bromide mixture and then dye. The addition of other sequences gave lower absorbance values under the same experimental conditions.

\section{Stoichiometry between $\mathrm{KBrO}_{3}$ and $\mathrm{STS}$}

The stoichiometry was established by mole ratio method. The results are shown in Figure 5. It is apparent from the figure that the combining molar ratio between $\mathrm{STS}$ and $\mathrm{KBrO}_{3}$ is $1: 1$ in the two cases. 


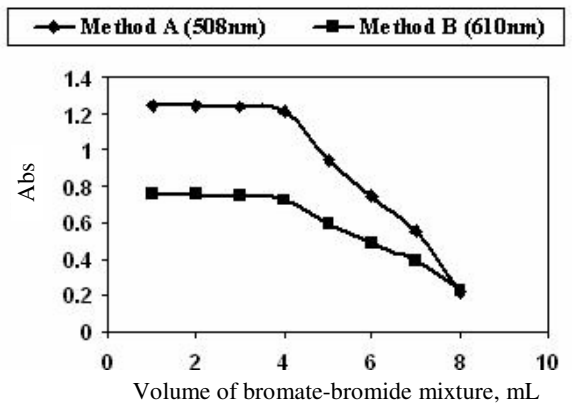

Figure 5. Method $\mathrm{A}$ at $5 \times 10^{-5} \mathrm{M}$ of STS and bromate-bromide mixture $\left(5 \times 10^{-5} \mathrm{M}\right.$ w.r.t $\left.\mathrm{KBrO}_{3}\right)$ and Method $\mathrm{B}$ at $1 \times 10^{-4} \mathrm{M}$ of STS and bromate-bromide mixture $\left(1 \times 10^{-4} \mathrm{M}\right.$ w.r.t $\mathrm{KBrO}_{3}$ )

\section{Validation of the proposed method}

\section{Linearity, limits of detection and quantitation}

Under the optimum conditions, the calibration graphs correlating the increase in the absorption intensity with the corresponding concentration of the drug were constructed. Regression analysis for the results were carried out using least-square method. In all cases, Beer's law plots were linear with good correlation coefficients as shown Table 1. The limits of detection (LOD) and limits of quantitation (LOQ) were determined ${ }^{17}$ using the formula: $\mathrm{LOD}$ or $\mathrm{LOQ}=\mathrm{kSDa} / \mathrm{b}$, where $\mathrm{k}=3.3$ for $\mathrm{LOD}$ and 10 for $\mathrm{LOQ}, \mathrm{SDa}$ is the standard deviation of the intercept, and $\mathrm{b}$ is the slope.

Table 1 Analytical and regression parameters of proposed methods

\begin{tabular}{lcc}
\hline Parameter & Method A & Method B \\
\hline$\lambda_{\max }, \mathrm{nm}$ & 508 & 610 \\
Beers law limit, $\mu \mathrm{g} / \mathrm{mL}$ & $0.2-1.6$ & $2-12$ \\
Ringbom limit, $\mu \mathrm{g} / \mathrm{mL}$ & $0.4-1.6$ & $2-12$ \\
Molar absorptivity, $\mathrm{L}$ mole ${ }^{-1} \mathrm{~cm}^{-1}$ & $1.898 \times 10^{5}$ & $2.71 \times 10^{4}$ \\
Sandell`s sensitivity, $\mu \mathrm{g} / \mathrm{cm}^{2}$ & 0.0021 & 0.0152 \\
Regression equation $(\mathrm{Y}=\mathrm{a}+\mathrm{bC})$ & & \\
Slope $(\mathrm{b})$ & 0.4613 & 0.0679 \\
Intercept $(\mathrm{a})$ & 0.0493 & 0.0032 \\
Correlation coefficient $\left(\mathrm{r}^{2}\right)$ & 0.9996 & 0.9985 \\
Standard deviation of slope $(\mathrm{Sb})$ & $3.7767 \times 10^{-3}$ & $1.3321 \times 10^{-3}$ \\
Standard deviation of intercept $(\mathrm{Sa})$ & $3.8143 \times 10^{-3}$ & $1.0376 \times 10^{-2}$ \\
Detection limit LOD, $\mu \mathrm{g} / \mathrm{mL}$ & 0.027 & 0.5 \\
Quantification limit LOQ, $\mu \mathrm{g} / \mathrm{mL}$ & 0.082 & 1.52 \\
\hline
\end{tabular}

\section{Precision and accuracy}

In order to determine the accuracy and precision of the proposed methods, solutions containing three different concentrations of STS were prepared and analyzed in five determinations. The relative standard deviation as precision and percentage relative error $(\mathrm{Er} \%)$ as accuracy of the suggested methods was calculated at $95 \%$ confidence levels, and can be considered satisfactory. The analytical results for accuracy and precision as shown in Table 2 reveal that the proposed methods have good repeatability. 
Table 2 Evaluation of precision and accuracy

\begin{tabular}{lcccccc}
\hline Proposed & \multicolumn{2}{c}{ Concentrations, $\mu \mathrm{g} / \mathrm{mL}$} & \multirow{2}{*}{ RSD, \% } & \multirow{2}{*}{ R E, \% } & \multirow{2}{*}{ SAE } & \multirow{2}{*}{ C.L } \\
\cline { 2 - 6 } method & Taken & Found \pm SD & & & & \\
\hline Method A & 0.4 & $0.402 \pm 0.007$ & 1.74 & 0.50 & 0.0031 & 0.009 \\
& 1.0 & $0.997 \pm 0.012$ & 1.21 & -0.30 & 0.0053 & 0.015 \\
& 1.6 & $1.599 \pm 0.012$ & 0.75 & -0.063 & 0.0053 & 0.015 \\
Method B & 4.0 & $3.99 \pm 0.043$ & 1.07 & -0.25 & 0.019 & 0.053 \\
& 8.0 & $8.06 \pm 0.074$ & 0.92 & 0.75 & 0.033 & 0.092 \\
& 12.0 & $12.01 \pm 0.094$ & 0.78 & 0.08 & 0.042 & 0.116 \\
\hline
\end{tabular}

${ }^{a}$ Mean value of five determinations; RE-Relative error; SD-Standard deviation; SAE-Standard analytical error; RSD-Relative standard deviation; C.L-Confident limit at $95 \%$

\section{Accuracy and recovery}

The accuracy and reliability of the methods were ascertained through recovery experiments. Pure STS was added at two different levels to pre-analyzed tablet powder and the total content was found by the proposed methods. The recoveries of the pure drug added to the tablet powder were shown in Table.3. The results reveal that the proposed methods are not liable to interference by tablet fillers, excipients and additives usually formulated with pharmaceutical preparations reveal that the average recoveries were in the range 98.91-101.2\% reflecting the high accuracy of the proposed method as indicated by low values of S.D

Table 3. Results of recovery experiments by standard addition method

\begin{tabular}{ccccc}
\hline \multicolumn{4}{c}{ Proposed methods } & $(\%)$ Recovery ${ }^{\mathrm{a}} \pm \mathrm{SD}$ \\
\hline $\begin{array}{c}\text { Proposed } \\
\text { methods }\end{array}$ & $\begin{array}{c}\text { Formulation } \\
\text { Taken, } \mu \mathrm{g} / \mathrm{mL}\end{array}$ & $\begin{array}{c}\text { Pure drug } \\
\text { Added, } \mu \mathrm{g} / \mathrm{mL}\end{array}$ & $\begin{array}{c}\text { Suminat-25 } \\
\text { tablets }\end{array}$ & $\begin{array}{c}\text { Suminat-50 } \\
\text { tablets }\end{array}$ \\
\hline Method A & 0.6 & 0.4 & $100.16 \pm 1.6$ & $98.91 \pm 0.63$ \\
& & 1.0 & $101.16 \pm 1.36$ & $101.2 \pm 1.1$ \\
Method B & \multirow{2}{*}{6.0} & 2.0 & $100.33 \pm 1.25$ & $100.16 \pm 1.04$ \\
& & 6.0 & $99.77 \pm 1.61$ & $100.61 \pm 1.75$ \\
\hline
\end{tabular}

${ }^{a}$ Mean value of three determinations

\section{Analysis of pharmaceutical formulations}

The method was successfully applied to the determination of sumatriptan succinate in tablets available locally. Satisfactory results (Table 4) were obtained for the recovery of drug and were in a good agreement with the label claim.

Table 4. Results of determination of sumatriptan succinate in formulations

\begin{tabular}{cccc}
\hline \multirow{2}{*}{ Samples $^{\#}$} & $\begin{array}{c}\text { Amount per } \\
\text { tablet, mg }\end{array}$ & \multicolumn{2}{c}{ \% Found ${ }^{*} \pm$ SD } \\
\cline { 3 - 4 } & 25 & $99.96 \pm 1.10$ & Method B \\
\hline Suminat $^{\mathrm{a}}$ & 50 & $101.04 \pm 1.78$ & $100.05 \pm 1.66$ \\
Suminat $^{\mathrm{b}}$ & & & $99.53 \pm 1.20$ \\
\hline
\end{tabular}

\section{Conclusion}

${ }^{*}$ Marketed by: $a$, $b$-Sun Pharma, India. *Mean value of five determinations

In conclusion, the proposed methods are more sensitive and free from such experimental variables as heating or extraction step. The methods depend on the use of simple and cheap chemicals and provide sensitivity comparable to that achieved by sophisticated and expensive technique like HPLC. Hence, they can be used for the routine analysis of sumatriptan succinate in quality control laboratories. 


\section{Acknowledgment}

The authors are thankful to Director, National Institute of Technology, Warangal for providing financial assistance and research facilities.

\section{References}

1. Ge Z, Tessier E, Neirinck L and Zhu Z, J Chromatogr B Analyt Technol Biomed Life Sci., 2004, 806(2), 299-303.

2. Majithiya R J, Majithiya J B, Umrethia M I and Murthy Y, Ars Pharmaceutica, 2006, 47, 199.

3. Boulton D W, Duncan G F and Vachharajani N N, Biomed Chromatogr, 2003, 17(1), 48-52.

4. Vachharajani N N, Shyu W C, Nichola P S and Boulton D W, Cephalalgia, 2002, 22(4), 282-287.

5. Dunne M and Andrew P, J Pharm Biomed Anal, 1996, 14, 721.

6. Andrew P D, Birch H L and Phillpot D A, J Pharm Sci., 1993, 82(1), 73-76.

7. Franklin M, Odontiadis J and Clement E M, J Chromatogr B Biomed Sci Appl, 1996, 681(2), 416-420.

8. McLoughlin D A, Olah T V, Ellis J D, Gilbert J D and Halpin R A, J Chromatogr A, 1996, 726, 115-124.

9. Shah C.R, Suhagia B.N, Shah N.J and Shah R.R, Indian J Pharm Sci., 2008, 70(6), 831.

10. Basavaiah K and Nagegowda P, ILFarmaco, 2004, 59, 147.

11. Basavaiah K and Nagegowda P, Oxid Commun., 2004, 27, 186.

12. Basavaiah K and Prameela H C, Indian J Pharm Sci., 2005, 67, 57.

13. Basavaiah K, Indian J Chem Technol., 2005, 12, 25-29.

14. Basavaiah K and Nagegowda P, J Braz Chem Soc., 2005, 16, 821.

15. Basavaiah K and Prameela H C, Anal Bioanal Chem., 2003, 376, 879.

16. Basavaiah K and Chandrashekar U, Acta Ciencia Indica Chem., 2003, 29, 25.

17. Validation of Analytical Procedures, ICH Harmonized Tripartite Guideline, Q2 (R1), Current Step 4 Version, Parent Guidelines 1996, Incorporated in November 2005. 


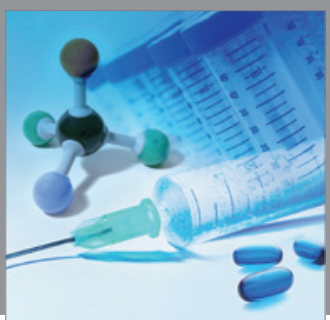

International Journal of

Medicinal Chemistry

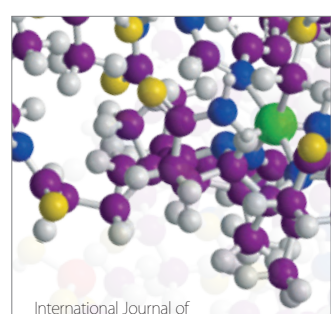

Carbohydrate Chemistry

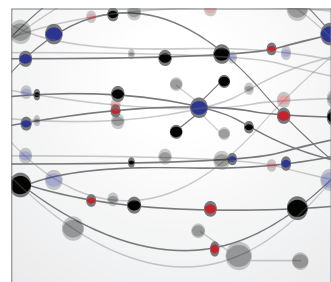

The Scientific World Journal
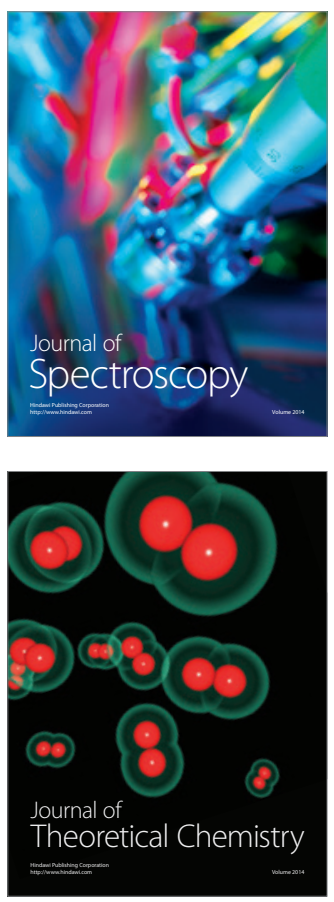
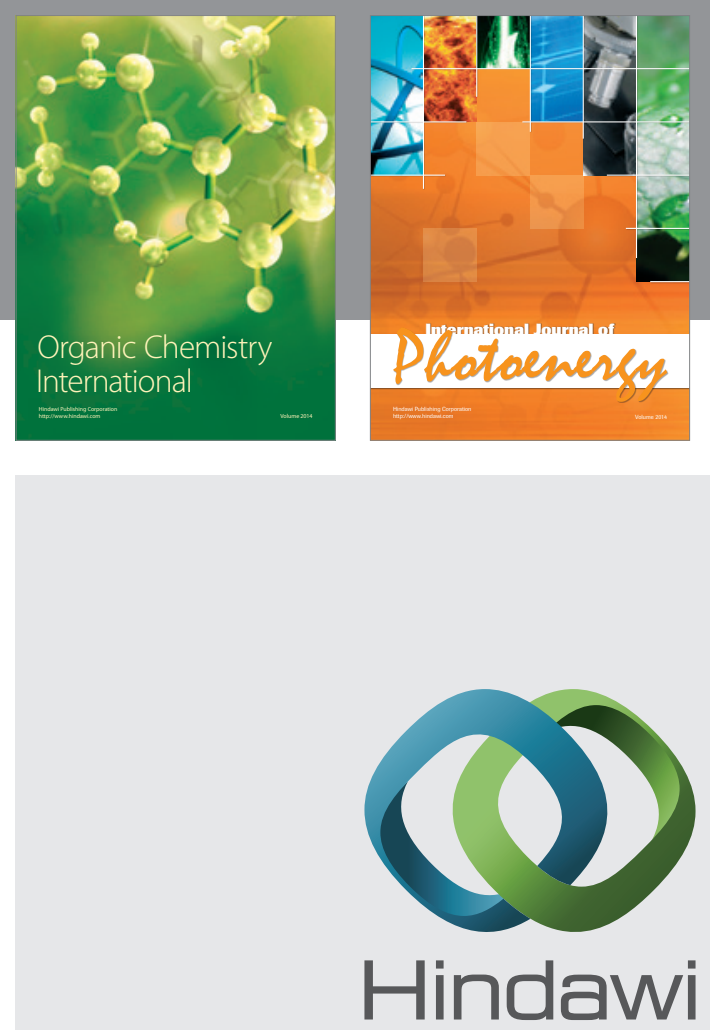

Submit your manuscripts at

http://www.hindawi.com
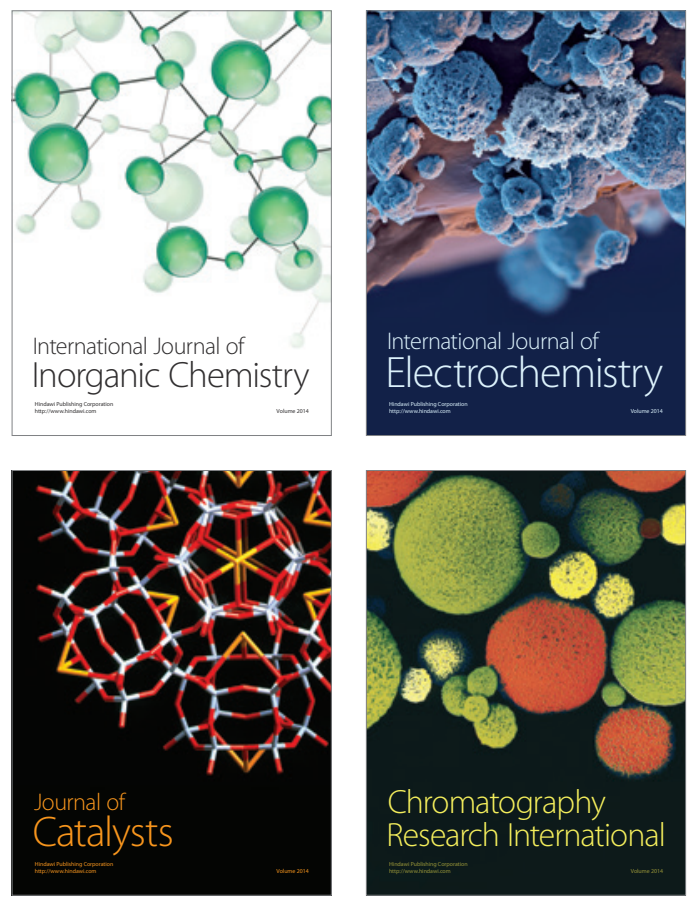
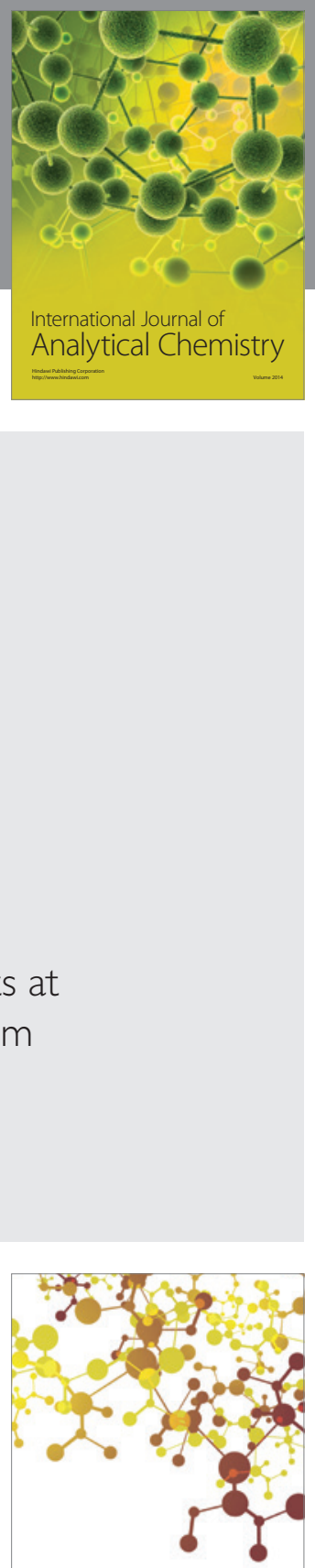

Journal of

Applied Chemistry
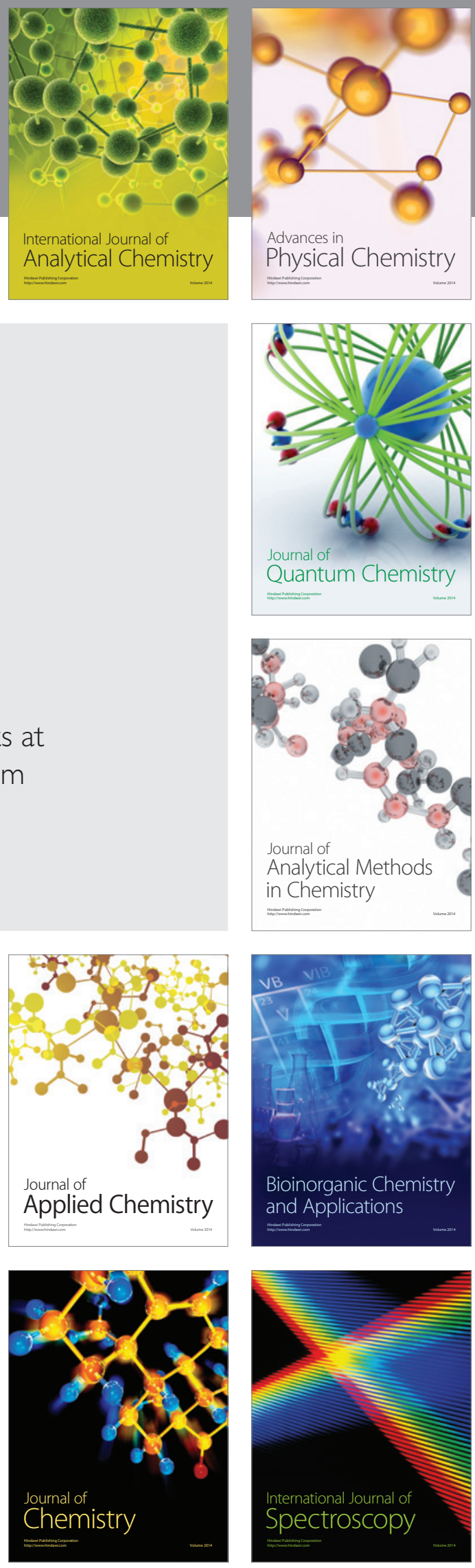